\title{
Parents, participation, partnership: Problematising New Zealand early childhood education
}

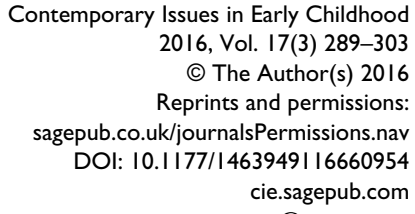

(\$SAGE

\author{
Angel Chan \\ University of Auckland, New Zealand
}

\section{Jenny Ritchie}

Victoria University of Wellington, New Zealand

\begin{abstract}
This article interrogates notions of teacher 'partnership with parents' within early childhood care and education settings in the context of Aotearoa (New Zealand). Te Whäriki, the New Zealand early childhood curriculum, clearly positions children's learning and development as being fostered when their families' cultures and practices are recognised. Yet findings from both national evaluative reports and recent studies indicate that, in many instances, families that are not members of the dominant cultural group do not experience this synergy. The authors draw on some recent national evaluative reports to paint a broad picture of the implementation of 'partnership', and then employ illustrative data from several research projects regarding the inclusion of Māori and Chinese families respectively. The authors apply hybridity theory, along with the related idea of funds of knowledge, to reinforce the need for teachers to proactively move beyond the hegemonic safe zones of traditional teacher-dominated practices towards opening up spaces of dialogic, fluid engagement with families whose backgrounds differ from their own. This aspect of teachers' professional responsibility is particularly important in the current era of increasing superdiversity.
\end{abstract}

\section{Keywords}

Chinese, cultural diversity, early childhood education, inclusion, Māori, partnership with parents

\section{Introduction}

In many Western countries, such as Aotearoa (New Zealand), there is a growing recognition of the 'cultural distance' between a teaching workforce that primarily represents the dominant culture, and the increasing ethnic diversity within the communities that they serve (Shonkoff, 2010: 363). 
This situation 'presents a clear challenge that has generated considerable rhetoric, yet relatively little productive action' (Shonkoff, 2010: 363). The relationship between teachers and families is recognised as key to bridging this cultural distance. Proactively fostering engagement with diverse families can therefore be considered a key professional responsibility of teachers working in culturally diverse communities.

In Aotearoa, the history of colonisation of the indigenous Māori by Britain involved the disavowal of commitments initially made to Māori regarding the retention of their lands, languages and everything else of cultural value to Māori (Waitangi Tribunal, 2011; Walker, 2004). The impacts of recent immigration policies mean that Aotearoa is now categorised as one of the few culturally and linguistically 'superdiverse' countries in the world, with more than 200 ethnic groups and over 160 languages (Royal Society of New Zealand, 2013; Spoonley, 2014). According to the $2013 \mathrm{New}$ Zealand census, Māori comprise $14.9 \%$ of the population, and immigrants from the People's Republic of China are the second-largest immigrant group (Statistics New Zealand, 2013).

Whilst official documents, such as the national early childhood curriculum Te Whāriki: He Whāriki Mātauranga mō ngā Mokopuna o Aotearoa (Ministry of Education, 1996) and reports from the Education Review Office (ERO), espouse the notion of 'partnership with parents', the application of this in practice appears to be uneven. The ERO is the body that oversees the quality of educational provision, and a series of its recent national evaluative reports identifies a gap between the rhetoric and reality of families' experiences within early childhood care and education (ECCE) settings (Education Review Office, 2010, 2012, 2013a). This article critically examines the nature of 'partnership' between teachers and parents/whānau ('extended families'), drawing on evidence from these ERO reports along with illustrative data from several studies which focus on the inclusion of Māori (Ritchie and Rau, 2006, 2008) and Chinese (Chan, 2014) families in New Zealand ECCE services. ${ }^{1}$ Analysis of our findings suggests that a majority of teachers enact static and predominately Western, monocultural ECCE discourses. Yet, when teachers do offer culturally responsive pedagogies, parents/families who are not from the dominant Pākehā (Western) culture are more likely to become engaged within the ECCE programme. This article applies hybridity theory (Bhabha, 1994) and the notion of funds of knowledge (González, 2005; González et al., 2005) as theoretical tools to analyse the findings and inform pedagogical strategies of engagement.

\section{Interrogating notions of 'parental involvement' and 'partnership'}

Notions of parent-teacher partnership and of parental involvement in their children's ECCE settings have been widely discussed nationally and internationally (Billman et al., 2005; GonzalezMena, 2007; Mitchell et al., 2006; Ward, 2009). This article, based on recent New Zealand-based research, firstly establishes that parental engagement within ECCE settings is a prerequisite to parent-teacher partnership, and that currently the nature and extent of enactment of this 'partnership' is problematic. The next section begins with an examination of the value of parental involvement both at home and in children's ECCE settings, before deconstructing the notion of 'partnership'.

\section{Parental involvement}

The value of parental involvement in children's activities at home in relation to learning and achievements is widely recognised (Gonzalez, 2009; Harper and Pelletier, 2010; Mitchell et al., 2006). Having an understanding of children's learning experiences at home is valuable knowledge for ECCE teachers. When teachers deepen their knowledge of children's participation within their family's and communities' activities, and then engender links to these experiences within the 
educational programme, children experience a continuity of understandings and expectations between home and education settings which, in turn, can foster their enthusiasm for learning (De Gioia, 2013; Hedges and Cooper, 2014; Rivalland and Nuttall, 2010).

Parental involvement in ECCE settings is often narrowly interpreted by teachers as the expectation that parents should follow the teachers' protocols for participating in and supporting the activities and routines of the ECCE centres, rather than engaging in decision-making with the teachers (Dahlberg and Moss, 2005; González, 2005). Parents, however, hold diverse perspectives regarding the parameters of their potential involvement (Knopf and Swick, 2007). Whilst some parents may be highly visible in the ECCE centres by working alongside children and/or being actively involved in curriculum decisions (Mercedes Nalls et al., 2009), parents with cultural backgrounds where teachers are respected as authority figures tend to view the idea of working alongside teachers as inappropriate, considering this to be intervening and disrespectful (De Gioia, 2013; Tobin et al., 2013; Ward, 2009). While immigrant parents with a non-English-speaking background may communicate with teachers infrequently, they may be highly engaged with their children's learning outside the ECCE settings - a form of involvement that is unobserved by teachers (Guo, 2005; Harper and Pelletier, 2010).

This form of 'invisible' parental involvement is similarly valid and effective in enhancing children's learning and development (Harper and Pelletier, 2010). Unfortunately, some teachers assume that parents who are not present within the learning settings are uninvolved and/or disinterested in their children's education (Banks, 2002; Knopf and Swick, 2007). Furthermore, monocultural teachers from the dominant culture may not be able to recognise the funds of knowledge that children from other ethnic backgrounds bring from their participation in the cultural activities of their families outside of the ECCE settings (Simon, 1990). These teachers may unwittingly reinforce the status quo (Mitchell et al., 2015), thereby hindering the development of parentteacher partnership.

\section{'Partnership' as espoused in New Zealand ECCE}

The aspiration of involving families in New Zealand ECCE is strongly evident in national institutional documents. Te Whāriki (Ministry of Education, 1996) highly values parent-teacher partnerships, requiring teachers to foster a sense of belonging for all families, to use culturally appropriate methods of communication, and to encourage family involvement in assessment and curriculum planning and evaluation.

Te Wharriki is philosophically grounded in recognition of the founding partnership between Māori and settlers, as represented in the 1840 Tiriti o Waitangi/Treaty of Waitangi, the agreement between Māori and the British Crown that legitimised British settlement. This can be described as a Tiriti/Treaty-based partnership. In its introduction, Te Whāriki states that 'all children should be given the opportunity to develop knowledge and an understanding of the cultural heritages of both partners to Te Tiriti o Waitangi', and explains that the 'curriculum reflects this partnership in text and structure' (Ministry of Education, 1996: 9). However, over many years, Treaty commitments made by the 'Crown' side of this partnership were repeatedly breached, to the serious detriment of Māori communities (Orange, 1987; Walker, 2004). More recently, the nation has been undergoing a Treaty settlement process, which partially addresses historical grievances. ${ }^{2}$

Meanwhile, whilst Māori continue to be recognised as the tangata whenua ('original people of this land'), the demographics of Aotearoa have altered significantly. Previous waves of immigration included people from a range of Pacific Islands, and more recently from Asian countries such as India and China (Spoonley and Bedford, 2012), providing a complex and diverse overlay within the 'Crown' component of the Tiriti/Treaty partnership. 
Within Te Whāriki (Ministry of Education, 1996), 'partnership' (haere kōtui) is expressly mentioned in the context of one of the four foundational principles: 'Family and Community - Whānau Tangata'. This principle recognises that the 'wider world of family and community is an integral part of the early childhood curriculum' (14), and that assessment of children's learning and development should include 'two-way communication that strengthens the partnership between the early childhood setting and families' (30). Te Whāriki recognises not only Māori, but the presence of Pacific Islands and other immigrant families, stating that 'culturally appropriate ways of communicating should be fostered, and participation in the early childhood education programme by whānau, parents, extended family, and elders in the community should be encouraged' (42). Teachers, through fostering these relationships, will thus be able to demonstrate that they 'respect the aspirations of parents and families for their children' (42).

In addition to its four principles, Te Whāriki contains five strands. Under the strand of 'Belonging - Mana Whenua', it states that 'families of all children should feel that they belong and are able to participate in the early childhood education programme and in decision making' (54). A link is made to the principle of 'Empowerment - Whakamana', whereby, through the practices associated with the strand of 'Belonging', 'families and the community are empowered' (54). A reflective question is asked under the strand of 'Contribution - Mana Tangata': 'In what ways and how well is the curriculum genuinely connected to the children's families and cultures?' (66). This question, as we shall explain further in this article, is one that could be usefully asked by all ECCE teachers and centre managers.

In the ECCE review model outlined by the ERO, the principle of partnership with parents is one of the central pillars (Education Review Office, 2013b). 'Priority questions' to be asked as part of a review process include: 'How effectively do the governors and managers of the service promote partnerships with parents and whānau?' (26) and 'How effectively do leaders work in partnership with parents and whānau to achieve positive outcomes for all children?' (29). An example of an evaluative indicator is that 'partnerships are based on genuine attitudes of acceptance, respect and willingness to listen and change' (37). The ERO guidelines for review of ECCE services state clearly that:

The principle of partnership in the Treaty needs to be reflected in the practices of the early childhood service. Working in partnership with Māori requires inclusive and collaborative practices between the early childhood service and whānau of tamariki Māori [Māori children] for the learning and wellbeing of Māori children. (Education Review Office, 2013b: 7)

It is therefore clear that, according to key New Zealand institutional documents (Education Review Office, 2013b; Ministry of Education, 1996, 2013) and ECCE literature (Gonzalez-Mena, 2007; Knopf and Swick, 2007), parent-teacher partnership involves a trusting, respectful relationship, two-way communication, collaboration, empowerment, equal power and shared decision-making, rather than parents being 'advised' about how to rear their children or expected to conform to the teachers' expectations. The following section contextualises how this form of partnership can, however, be challenging for some Chinese families.

\section{Problematising the notion of parent-teacher partnership within a Chinese context}

Google translates the term 'partnership' as 合作矢系/he zuo guan xi. 合作/He zuo means 'cooperation'/'collaboration' and 矢系/guan xi means 'relationship'. The notion of guan xi within Chinese contexts has been discussed often, but is mostly suggested as a strategy for non-Chinese 
to engage in business with the Chinese (Langenberg, 2007; Luo, 2007; Wong and Leung, 2001). The discourse of partnership is not evident within Chinese teaching and learning contexts, which are still strongly influenced by Confucianism and collectivism.

Due to the impacts of globalisation, urbanisation, telecommunications and information technologies, and the concomitant increased exposure to 'Western' cultures, socialisation goals for children in Chinese societies like China and Hong Kong are transforming (Chen and Li, 2012; Pearson, 2011; Rao et al., 2009). Confucianism may no longer be practised 'religiously', and contemporary Chinese parenting, teaching and learning practices are far from homogeneous. Nonetheless, much current research still applies the ancient philosophy of Confucianism to understanding and explaining Chinese family values and parenting practices (Chan, 2006, 2009; Luo et al., 2013), and the education and academic achievement of Chinese students (Li, 2004; Li and Cutting, 2011; Wu and Singh, 2004). Research further indicates that Chinese immigrant families who are living in English-speaking and non-Chinese-dominated societies, including New Zealand, continue to deploy certain traditional Confucian beliefs in the parenting and education of their children (Chan, 2006; Li, 2004).

Confucianism places a high value on education (De Bary, 2007; Lee, 1996; Li, 2009). For many contemporary Chinese, educational achievement is considered to be imperative for future social status and honour, as well as career and economic success (Li, 2009; Woodrow and Sham, 2001). Parents are considered as having performed their duties well when their children have achieved academic excellence (Cheah and Li, 2010; Wu and Singh, 2004).

Research has also identified notions of collectivism as key factors in shaping the family-focused and community-oriented nature of most Chinese (Lee, 1996; Rao and Chan, 2009). Collectivism is an aspect of Confucianism (Luo et al., 2013) and stresses social harmony (Lee, 1996; Rao and Chan, 2009). Together, Confucianism and collectivism promote harmonious yet hierarchically structured social relationships (Haley et al., 1998; Jiang, 2006), and contemporary Chinese children are still expected to be submissive recipients of knowledge and to engage in learning processes that are highly structured, dogmatic, didactic and teacher-centred (Cheng, 2006; Yuen and Grieshaber, 2009). Since Chinese parents influenced by Confucianism and collectivism consider a teacher to be someone with high social status and authority, it is likely that they may find Western discourses of parent-teacher partnership disrespectful and inappropriate. Nonetheless, since Chinese families are very concerned about their children's education, they are also likely to be eager to engage in partnership with teachers if the benefits of parent-teacher partnership are thoroughly understood. The paradigms of hybridity theory and funds of knowledge are outlined in the following section as tools for opening up discursive possibilities around the notion of 'partnership' with parents.

\section{Theorising hybrid funds of knowledge}

Applying ideas from hybridity theory (Bhabha, 1994) and the notion of funds of knowledge (González, 2005) opens up possibilities for shifting beyond universal and static definitions of 'partnership'. Hybridity theorising challenges essentialism and homogeneity. It recognises the non-static and unsettled nature of cultures and discourses as being in a continuous process of hybridisation, and it celebrates the creation of 'third spaces' (Bhabha, 1994, 1996), which allows for new possibilities to emerge across both time and space.

The concept of funds of knowledge focuses on practices rather than culture; it examines what families do and how the family members articulate what they do (González, 2005; González et al., 2005). The daily activities of families are viewed as 'a manifestation of particular historically accumulated funds of knowledge that households possess' (González, 2005: 41). Te Whāriki aligns with the concept of funds of knowledge in recognising that 'parents and caregivers have a 
wealth of valuable information and understandings regarding their children' (Ministry of Education, 1996: 30).

Whilst the fluidity and pragmatism of people's lives is recognised in hybridity theory (Bhabha, 1994, 1996), the metaphor of 'borderlands' is used to highlight how families continuously select new and pragmatic strategies to adapt or replace their existing practices (González, 2005; González et al., 2005). Bhabha (1994: 25) suggests using a 'dialectical' approach that involves 'negotiation rather than negation' to articulate cultural hybridity. In alignment with Bhabha's ideas, González (2005) claims that during the process of border/spatial-crossings, individuals adapt existing knowledge and create new funds of familial knowledge. Hybrid discourses open up spaces of negotiation rather than assimilation.

Recognition of the hybrid and fluid nature of families' beliefs and practices brings acknowledgement also of variety in perspectives of 'partnership'. Families with diverse cultural and linguistic backgrounds have a depth of hybrid funds of knowledge to contribute to the New Zealand ECCE community. By recognising the fluidity of knowledge and practices across space and time, and integrating non-dominant discourses and non-institutional knowledge into mainstream curriculum and pedagogy, institutional practices may become open to continual transformation.

\section{Findings from national evaluative reports}

The New Zealand ERO conducts systematic evaluations of all education settings, regularly combining findings from these into national evaluative reports with specific focuses. A 2004 ERO report, Catering for diversity in early childhood services, was critical of the way that ECCE services responded to the challenges of engaging with 'difference', stating that 'provision for diversity of cultures needs to move beyond tokenism to a deeper understanding of how service provision impacts on different cultures' (Education Review Office, 2004: 16). This report further signalled the potential crossover benefits when teachers were able to enhance their provision for Māori families, in that they could potentially apply similar skills and strategies in engaging with those from diverse cultural backgrounds:

There was a strong correlation between the quality of provision of te reo and tikanga Māori and the provision for the differing cultures of families contributing to services. Rather than biculturalism and multiculturalism being alternatives, it appears that attention to one had positive benefits for the other. (Education Review Office, 2004: 11)

More recently, a 2010 ERO national evaluative report, Success for Māori children in early childhood services, recommends that ECCE services need to prioritise work to 'develop or review their processes for consulting and communicating with the parents and whānau of Māori children so they can be more responsive to their aspirations and expectations', and that the Ministry of Education should fund professional learning programmes for teachers that include 'a focus on supporting early childhood services to be responsive to Māori children and their whānau' (Education Review Office, 2010: 2).

The 2012 ERO wider national evaluative report, Partnership with whānau Māori in early childhood services, was highly critical of teachers' practices in relation to their partnerships with Māori families:

Unfortunately most centres demonstrated limited partnership with whānau Māori. Ninety percent did not work in partnership with whānau Māori and expected that Māori children and their whānau would 'fit in' to the centre's culture. Some made deficit assumptions ... claiming that Māori did not value education. 
Others expressed views that demonstrated their lack of understanding of whānau skill, knowledge and expertise ... The professional leaders in these services were driven by the notion that all children and families must be 'treated the same'.

The view of partnership held by these services was limited and did not extend past good relationships. Most professional leaders in early childhood services had yet to realise the potential of partnership to provide a bicultural programme that fully supported the language, culture and identity of Māori children and their whānau ... Many interactions and relationships established with Māori failed to reflect Māori ways of interacting and relationship building. Educators and managers waited for Māori to come to them, and face-to-face communication was limited so services assumed that Māori whānau were uninterested in developing relationships. (Education Review Office, 2012: 15)

Whilst many services made reference to these parent-teacher partnership commitments in their philosophy statements, 'only a few services were fully realising such intent in practice by working in partnership with whānau Māori' (Education Review Office, 2013a: 13). The ERO data further demonstrated that centres' internal programme evaluation, or 'self-review', 'was an area to be strengthened in many services, particularly in relation to the responsiveness of their curriculum to the aspirations of parents and whānau' (Education Review Office, 2013c: 22). These reports signal that there is a significant gap between the espoused pedagogies and those that are being enacted in the vast majority of services with regard to teachers implementing their professional responsibility to engage with families. Although none of the above ERO reports make specific reference to Chinese families, the findings to be presented in the next section show that many of the ERO comments regarding teacher partnership with Māori families are applicable to the experiences of Chinese immigrant participants.

\section{Findings from research projects}

The following sections highlight certain findings from the recent research of the authors in relation to notions of 'partnership' with parents in New Zealand ECCE services. ${ }^{3}$ Firstly, Angel Chan (2014) offers some insights from her recent doctoral study, which focused on Chinese parents' views in relation to their engagement within kindergartens, and then Jenny Ritchie draws on data from two projects which focused on the involvement of Māori families in ECCE (Ritchie and Rau, 2006, 2008) and were funded by the New Zealand Teaching and Learning Research Initiative. Jenny Ritchie was a supervisor of Angel Chan's doctoral work and, during this process, it became evident that there were some interesting interconnections and tensions in relation to notions of teacher 'partnership' and engagement with both Māori and Chinese families. All of these studies utilised qualitative narrative methodologies, which have previously been reported fully in the full thesis and research reports.

\section{Chinese parents in New Zealand kindergartens}

Previous New Zealand studies indicate a lack of partnership between ECCE teachers and Chinese immigrant parents (Guo, 2010; Wu, 2011), and the more recent doctoral project (Chan, 2014) yielded a similar result. Ten immigrant parents, recruited from three Auckland kindergartens, participated in two phases of individual interviews. The narratives collected indicate a high degree of parental involvement of the participants in out-of-kindergarten contexts. For example, parents accompanied their children to a range of extracurricular activities and engaged them frequently in literacy and numeracy exercises at home. Yet they participated in the kindergartens minimally and 
passively, and parent-teacher partnership, based on the definitions provided earlier as stated in the institutional documents, did not exist.

Their participation in the kindergartens reflected more of an attitude of compliance, responding and conforming to teachers' expectations. For instance, the participants mainly acted as parent helpers and supported the teachers with routines and activities. Nevertheless, none of them expressed an eagerness to be involved:

Jan: I normally participate in the usual activities ... I don't stay at the kindergarten regularly. If I have time, I will go there early, and if they don't have parent help for the day, I will help ... but I always go with them [the children] to those excursions.

Ella: I signed up for different activities. I helped with the setting up, tidying up and decorating the kindergarten. It depends ... Since I have so much time, I actually want to help more at 'kindy' [kindergarten], but I have a feeling that the 'kindy' does not need any help. ${ }^{4}$

The attitude of compliance is linked to the work of many researchers, who claim that Chinese parents tend to perceive teachers as having great authority and are therefore not to be challenged (Chan, 2006; Guo, 2005; Woodrow and Sham, 2001; Wu, 2011). Whilst Te Whāriki (Ministry of Education, 1996) and the philosophy statements of the kindergartens state that parents should be encouraged to offer ideas and suggestions to improve the operation of kindergartens, the participants were unwilling to be involved in discussion and decision-making:

Jean: I think it's cultural difference. This kind of autonomy operation, using a [parent] committee to run the kindergarten, is very rare in China. Parents [in China] are seldom expected to be involved. In here [New Zealand], the way of doing things is different.

Parental involvement in ECCE settings and creating a sense of community and belonging for families are interrelated, and, as mentioned previously, they are emphasised in many New Zealand official documents, including Te Whāriki (ECE Taskforce, 2011; Education Review Office, 2004, 2011; Ministry of Education, 1996). However, the participants' responses highlight cultural differences regarding the discourse of parental involvement in ECCE settings:

Katie: To us [Chinese], we feel that schools and kindergartens are places where children learn, not communities that we have to integrate into. In China, families see schools and kindergartens as places to learn, and when children come home, we stop our connections with the learning institutions. We don't believe that we [parents] have to participate in kindergarten or school activities, or to know each other in the kindergarten very well. We don't consider schools or kindergartens as communities.

The participants believed that ECCE centres are simply places where children learn, not communities into which they should integrate, and therefore they did not see a sense of belonging and community as necessary. The participants also believed that the teachers were very knowledgeable and capable, and that parents need not contribute much to supporting the teachers. These findings align with literature which claims that Chinese parents accord teachers with respect (Rao et al., 2009) and that their engagement in New Zealand ECCE settings is limited (Guo, 2010; Wu, 2011).

According to the participants, their concerns regarding their children's early learning were often not taken seriously by teachers: 
Sonia: But they [the teachers] said this is the education style here, 'free play' ... When I raised my concerns about Jess [her son] not reading and writing, the teachers told me, 'He will get there'. It was the same in the previous centre. Every time I asked the teachers, they would say, 'He's doing well' ... They [the teachers] told me children will learn when they start primary school.

Nan: Teachers will tell you children 'learn very quickly' and [you] don't have to worry. But we know so well that if my children don't know English, they will find it very tough and be very upset [at primary school] ... I told the teachers he [her son] did not know any English at all, hoping that they would teach him some English, and of course they didn't, so now I don't have this expectation any more.

Parents who have experienced previous negative encounters with teachers are likely to lack the confidence to engage with them (Tobin et al., 2013; Ward, 2009). When their concerns and aspirations had been disregarded by teachers, they felt disempowered and lost the motivation to make further suggestions and requests. Other studies which involved Asian (including Chinese) immigrant families also indicate that these families believe there is no value in sharing their disagreement with teachers (De Gioia, 2013; Guo, 2005, 2010; Wu and Singh, 2004).

These narratives suggest that teachers may have been unprepared to consider practices as fluid and hybrid (Bhabha, 1994), and to incorporate diverse families' funds of knowledge (González, 2005 ) into centre practices, thus reflecting power asymmetries between immigrant parents and teachers in ECCE settings (Ali, 2008; Tobin et al., 2007). Teachers' practices are organised and structured mainly by institutional discourses (Rivalland and Nuttall, 2010), such as the 'free play' mentioned by Sonia. Yet, in ostensibly supporting institutional expectations and dominant discourses, the teachers are paradoxically silencing and negating certain parental aspirations, rather than applying a dialectical approach (Bhabha, 1994) which considers diverse hybrid funds of knowledge to be negotiable.

\section{Working with Māori families in New Zealand ECCE settings}

The diverse range of services in Aotearoa includes two forms of parent/whānau-based early childhood provision: Playcentre and Kōhanga Reo (May, 2009). Playcentre has had a strong commitment to including Māori families, although this has sometimes been problematic for Māori families within Pākehā/Western-dominated settings (McDonald, 1973; Ritchie and Rau, 2015). Kōhanga Reo is a service provided by Māori, for Māori, which is whānau- and mostly tribally based and focused on the Māori language and culture (Skerrett, 2007).

The majority (over 80\%) of Māori children attend services other than Kōhanga Reo - that is, 'mainstream' kindergartens and education and care settings (Education Counts, 2014). Yet only 8.5\% of early childhood teachers are Māori (Education Counts, 2013) and merely 1.6\% of Pākehā (people of European ancestry) speak the Māori language (Ministry of Social Development, 2010). This section reports selections of previously unpublished data from two studies (Ritchie and Rau, 2006, 2008) that aimed to identify examples of the kinds of Tiriti/Treaty-based practice advocated in Te Whäriki and which would demonstrate that genuine culturally responsive parent-teacher partnership is attainable.

Whilst Pākehā teachers were aware of the expectations contained within Te Whäriki regarding the inclusion of Māori families, along with Māori content and practices in ECCE programmes, they often reported feeling challenged regarding their sense of inadequacy in this regard. In the following example, an experienced kindergarten head teacher described challenges she had initially felt in working towards the goal of relating with whānau Māori: 
Anne: Instead of being able to relate in a natural way with Māori families, I felt shy and awkward. Sometimes Māori people would tell me where I had gone wrong in no uncertain terms. My only solution was to try to learn as much as possible about Māori culture and Tikanga ... I often get confused and wonder whether it's worth making the effort to try to understand. For instance, should I learn to speak Māori proficiently? If I mistakenly speak Te Reo Māori to a non-Māori-speaking parent, I can make them feel inadequate and uncomfortable.

Anne and many of the other Pākehā teachers in this study had persevered in their endeavours to offer whānau-inclusive practice. These committed educators acknowledged that they faced many challenges, some of which came from the attitudes of the Pākehā parents who belonged to those centre communities. A Māori Playcentre educator explained the difficulties experienced by the Pākehā teacher 'Diane' at their local Playcentre in a small rural community when, despite her commitment to increasing the Māori components within their programme, Pākehā parents were unsupportive to her efforts: 'Well, sometimes I get the feeling it's more like: "Why are you doing that?" I think it's a bit more than resistance, isn't it? Antagonistic'.

Despite these barriers, our data contains many examples of ways in which committed teachers were bridging the gap between rhetoric and practice in relation to encouraging the engagement of Māori families. Key to this engagement was the proactive inclusion of Māori ways of being, knowing, doing and relating within the centre programme. For Māori whānau, their 'engagement, participation, responsiveness, and contribution in early childhood settings was enhanced through programmes in which educators affirmed and enacted Māori values' (Ritchie and Rau, 2008: 3). These values and practices were often negotiated and validated through relationships with Māori families and elders.

For some Māori families, the experience of te ao Māori (the 'Māori world') that was offered to their children was an opportunity to reconnect with their language and culture, which had been denied to them due to the impact of colonisation. These families were particularly appreciative when their funds of knowledge were recognised by ECCE teachers, as this Māori mother expressed:

Sheena: I feel the teaching of Te Reo [the Māori language] at [this kindergarten] is giving [my son] a great foundation to carry on learning and encourages his interest in te ao Māori. This is also true for me as a parent and I deeply appreciate this (as in making me remember what I know and using it!).

These studies, whilst revealing the limitations and challenges faced by teachers in delivering programmes that engaged Māori families, also illuminated some promising pathways whereby Pākehā teachers demonstrated their dispositions of humility, openness and respect for Māori families' funds of knowledge. Through experiencing these pedagogies of respectful, responsive listening, Māori families have willingly contributed to the ECCE centres' pedagogies and programmes within these settings. Yet teachers and programmes that enact these pedagogies are rare, according to recent ERO reporting (Education Review Office, 2010, 2012, 2013a). In the following section, we continue to apply hybridity theory (Bhabha, 1994) to examine the fluidity of parenting practices, and the notion of funds of knowledge (González, 2005; González et al., 2005) to highlight the value of including families' diverse knowledge in curriculum and pedagogy. 


\section{Pedagogical implications: embracing diverse fluid and hybrid funds of knowledge}

As people become increasingly mobile and, in particular, as mass human migration is further increased by the impending climate crisis (Weber, 2015), cultural boundaries may be weakened, and beliefs and practices become subject to transformation. Teachers, as cultural workers (Freire, 2005), operate at the interstices of (inter)cultural shifts and boundaries. Understanding and applying concepts from hybridity theory and its associated notion of 'third spaces' can enable new pedagogical possibilities and multiplicities (Bhabha, 1994). Education discourses such as 'parent-teacher partnership', previously redolent of top-down teacher-directed modes, may then open up to become fluid, responsive and specific to particular families, teachers and ECCE communities. The data presented in this article shows that cultural differences in perceptions of parental involvement in learning institutions have discouraged Chinese immigrant parents from being active agents in ECCE settings. For Māori families, at least, when their cultural and spiritual values are reflected in the ECCE settings, this elicits a sense of well-being and fosters further engagement within that setting, highlighting the value of including hybrid familial funds of knowledge (González, 2005).

The narrative excerpts presented in this article, along with recent ERO reports, illustrate that some ECCE teachers are not prepared to embrace parental aspirations that are different from their 'normal' practices (Education Review Office, 2010, 2012, 2013c). Despite 'empowerment' being a key principle of Te Whāriki (Ministry of Education, 1996), it appears that in many cases teachers are enacting a disempowering definition of parental involvement, whereby families are expected to conform to uncritiqued, long-standing institutional discourses. This approach to parental involvement not only fails to utilise familial and community funds of knowledge as required by Te Whäriki, but it also perpetuates an asymmetrical power relation between parents and teachers (Mitchell et al., 2006).

When teachers embrace the notion of funds of knowledge and apply a dialectical approach, as suggested in hybridity theory (Bhabha, 1994), to negotiate differences and engage in dialogue with parents from diverse backgrounds (Hedges and Cooper, 2014), diverse voices can be heard, revealing the varied knowledges of families, their social networks and communities (González et al., 2005). This kind of dialogue identifies parental aspirations and expectations, along with children's and families' particular interests, recognising and affirming those that may not be congruent with the dominant discourses. This gives rise to many 'third space' (Bhabha, 1994, 1996) encounters, empowering parents to work in partnership with teachers. More importantly, learning becomes more meaningful, contextualised and effective when home and community knowledge that children are already familiar with is integrated into the education setting (González et al., 2005). Te Whāriki, whilst avowedly a bicultural curriculum, also recognises the cultural heritages of immigrants in New Zealand and the valuable funds of knowledge contributed by diverse families (Ministry of Education, 1996). In response to the superdiversity of contemporary Aotearoa, it is now particularly timely for ECCE teachers to enact these visions of the curriculum.

\section{Conclusion}

Recent New Zealand education reports and research, as sampled and analysed above, point to the ongoing issue of teacher complacency in the face of challenging demographic disjunctures, both historical, in relation to settler colonisation of the indigenous Māori, and contemporary, as increasing global migration trends now position New Zealand as 'superdiverse' (Royal Society of New Zealand, 
2013; Spoonley, 2014). Instead of retreating into habitual practices of 'treating all children the same', teachers are now challenged to respond to these concerns by interrogating their practices and, in particular, those in relation to fostering genuine, dialogical relationships with parents from all participating families. Whilst our findings show that both Māori and Chinese communities had experienced institutional disempowerment, they also demonstrate that, through proactively generating such relationships with these families, teachers may empower them to regain the confidence to participate in ECCE settings. Particular strategies for fostering such relationships and promoting dialogue need to be contextually responsive and will take time to develop (Tobin et al., 2013). The research cited in this article supports calls for more professional learning opportunities for ECCE educators (Education Review Office, 2010, 2012), along with raising questions for the consideration of initial teacher education qualification providers with regard to the preparedness of beginning teachers to offer culturally resonant pedagogies.

\section{Funding}

The author(s) disclosed receipt of the following financial support for the research, authorship, and/or publication of this article: Two of the studies drawn upon in this paper (Ritchie and Rau, 2006, 2008) received funding from the New Zealand Teaching and Learning Research Initiative.

\section{Notes}

1. Some of the content of this article is drawn from a recent doctoral thesis (Chan, 2014).

2. For further details of the Treaty settlement process, see the website of the Waitangi Tribunal at http:// www.waitangi-tribunal.govt.nz

3. All of the studies received ethical approval from the relevant institutional review board. Actual names have been changed. For detailed explanations of the methodologies used in these studies, see the original reports in Chan (2014) and Ritchie and Rau (2006, 2008).

4. Whilst the interviews were mainly conducted in Mandarin and/or Cantonese, the speech marks around terms such as 'kindy' in this excerpt indicate that the participant in this instance used the English term.

\section{References}

Ali MA (2008) Loss of parenting self-efficacy among immigrant parents. Contemporary Issues in Early Childhood 9(2): 148-160.

Banks JA (2002) An Introduction to Multicultural Education. Boston, MA: Allyn and Bacon.

Bhabha HK (1994) The Location of Culture. London: Routledge.

Bhabha HK (1996) Culture's in-between. In: Hall S and Du Gay P (eds) Questions of Cultural Identity. London: SAGE, pp. 53-60.

Billman N, Geddes C and Hedges H (2005) Teacher-parent partnerships: Sharing understandings and making changes. Australian Journal of Early Childhood 30(1): 44-48.

Chan A (2006) 'The teachers said my child is different': The first years/ngā tau tuatahi. New Zealand Journal of Infant and Toddler Education 8(1): 34-38.

Chan A (2009) Critical multiculturalism: The challenge of multiculturalism within a New Zealand bicultural context - a Chinese perspective. International Journal of Equity and Innovation in Early Childhood 7(1): 29-40.

Chan A (2014) The politics of identity, belonging and exclusion: Chinese immigrant parents' involvement in New Zealand early childhood education. PhD Thesis, Massey University, Albany, New Zealand.

Cheah CSL and Li J (2010) Parenting of young immigrant Chinese children: Challenges facing their socialemotional and intellectual development. In: Grigorenko EL and Takanishi R (eds) Immigration, Diversity, and Education. New York: Routledge, pp. 225-241.

Chen XY and Li D (2012) Parental encouragement of initiative-taking and adjustment in Chinese children from rural, urban, and urbanized families. Journal of Family Psychology 26(6): 927-936.

Cheng DPW (2006) The translation of western teaching approaches in the Hong Kong early childhood curriculum: A promise for effective teaching? Contemporary Issues in Early Childhood 7(3): 228-237. 
Dahlberg G and Moss P (2005) Contesting Early Childhood: Ethics and Politics in Early Childhood Education. Abingdon: RoutledgeFalmer.

De Bary WT (2007) Confucian Tradition and Global Education. Hong Kong, China: Chinese University Press.

De Gioia K (2013) Cultural negotiation: Moving beyond a cycle of misunderstanding in early childhood settings. Journal of Early Childhood Research 11(2): 108-122.

ECE Taskforce (2011) An Agenda for Amazing Children: Final Report of the ECE Taskforce. Wellington, New Zealand: Ministry of Education. Available at: http://www.researchconnections.org/childcare/ resources/21777

Education Counts (2013) Annual ECE census: Report 2013. Wellington, New Zealand: Ministry of Education. Available at: http://www.educationcounts.govt.nz/statistics/ece2/staffing-publications/annual-ece-summary-reports

Education Counts (2014) Annual ECE census report 2014. Wellington, New Zealand: Ministry of Education. Available at: https://www.educationcounts.govt.nz/statistics/early-childhood-education/annual-ecesummary-reports

Education Review Office (2004) Catering for diversity in early childhood services. Wellington, New Zealand: Education Review Office.

Education Review Office (2010) Success for Māori children in early childhood services. Wellington, New Zealand: Education Review Office. Available at: http://www.ero.govt.nz/publications/success-formaori-children-in-early-childhood-services/

Education Review Office (2011) Positive foundations for learning: Confident and competent children in early childhood services. Wellington, New Zealand: Crown Copyright.

Education Review Office (2012) Partnership with whānau Māori in early childhood services. Wellington, New Zealand: Education Review Office. Available at: http://www.ero.govt.nz/National-Reports/ Partnership-with-Whanau-Maori-in-Early-Childhood-Services-Feb-2012

Education Review Office (2013a) Working with Te Whāriki. Wellington, New Zealand: Education Review Office.

Education Review Office (2013b) He pou tātaki: How ERO reviews early childhood services. Wellington, New Zealand: Education Review Office. Available at: http://www.ero.govt.nz/how-ero-reviews/eroreviews-of-early-childhood-services-and-kohanga-reo/

Education Review Office (2013c) Priorities for children's learning in early childhood services. Wellington, New Zealand: Education Review Office. Available at: http://www.ero.govt.nz/publications/prioritiesfor-childrens-learning-in-early-childhood-services-good-practice/

Freire P (2005) Teachers as Cultural Workers: Letters to Those Who Dare Teach. Boulder, CO: Westview Press.

González N (2005) Beyond culture: The hybridity of funds of knowledge. In: González N, Moll L and Amanti C (eds) Funds of Knowledge: Theorizing Practices in Households, Communities, and Classrooms. Mahwah, NJ: Lawrence Erlbaum Associates, pp. 29-46.

González N, Moll L and Amanti C (2005) Introduction: Theorizing practices. In: González N, Moll L and Amanti C (eds) Funds of Knowledge: Theorizing Practices in Households, Communities, and Classrooms. Mahwah, NJ: Lawrence Erlbaum Associates, pp. 1-24.

Gonzalez V (2009) Young Learners, Diverse Children: Celebrating Diversity in Early Childhood. Thousand Oaks, CA: Corwin.

Gonzalez-Mena J (2007) 50 Early Childhood Strategies for Working and Communicating with Diverse Families. Upper Saddle River, NJ: Pearson Education.

Guo K (2005) Asian immigrant parents' and New Zealand early childhood teachers' views of parent-teacher relationships. New Zealand Research in Early Childhood Education 8: 125-135.

Guo KL (2010) Chinese immigrant children in New Zealand early childhood centres. PhD Thesis, Victoria University of Wellington, Wellington, New Zealand.

Haley GT, Tan CT and Haley UCV (1998) New Asian Emperors: The Overseas Chinese, Their Strategies and Competitive Advantages. Oxford: Butterworth-Heinemann.

Harper SN and Pelletier J (2010) Parent involvement in early childhood: A comparison of English language learners and English first language families. International Journal of Early Years Education 18(2): $123-141$. 
Hedges H and Cooper M (2014) Inquiring minds, meaningful responses: Children's interests, inquiries, and working theories. Wellington, New Zealand: Teaching and Learning Research Initiative. Available at: $\quad$ http://www.tlri.org.nz/tlri-research/research-completed/ece-sector/inquiring-minds-meaningfulresponses-children $\% \mathrm{E} 2 \% 80 \% 99 \mathrm{~s}$

Jiang X (2006) The concept of the relational self and its implications for education. Journal of Chinese Philosophy 33(4): 543-555.

Knopf HT and Swick KJ (2007) How parents feel about their child's teacher/school: Implications for early childhood professionals. Early Childhood Education Journal 34(4): 291-296.

Langenberg EA (2007) Guanxi and Business Strategy: Theory and Implications for Multinational Companies in China. London: Springer.

Lee WO (1996) The cultural context for Chinese learners: Conceptions of learning in the Confucian tradition. In: Watkins DA and Biggs JB (eds) The Chinese Learners: Cultural, Psychological and Contextual Influences. Hong Kong, China: Comparative Education Research Centre, University of Hong Kong and Australian Council for Educational Research, pp. 23-41.

Li J (2004) Parental expectations of Chinese immigrants: A folk theory about children's school achievement. Race, Ethnicity and Education 7(2): 167-183.

Li J (2009) Learning to self-perfect: Chinese beliefs about learning. In: Chan CKK and Rao N (eds) Revisiting the Chinese Learner: Changing Contexts, Changing Education. Hong Kong, China: Comparative Education Research Centre, University of Hong Kong, pp. 35-69.

Li X and Cutting J (2011) Rote learning in Chinese culture: Reflecting active Confucian-based memory strategies. In: Jin L and Cortazzi M (eds) Researching Chinese Learners: Skills, Perceptions and Intercultural Adaptations. New York: Palgrave Macmillan, pp. 21-42.

Luo R, Tamis-LeMonda CS and Song L (2013) Chinese parents' goals and practices in early childhood. Early Childhood Research Quarterly 28(4): 843-857.

Luo Y (2007) Guanxi and Business. New Jersey, NJ: World Scientific.

McDonald G (1973) Māori Mothers and Pre-school Education. Wellington, New Zealand: New Zealand Council for Educational Research.

May H (2009) Politics in the Playground: The World of Early Childhood in New Zealand. 2nd ed. Dunedin, New Zealand: Otago University Press.

Mercedes Nalls A, Mullis RL, Cornille TA, et al. (2009) How can we reach reluctant parents in childcare programmes? Early Child Development and Care 180(8): 1053-1064.

Ministry of Education (1996) Te Whāriki. He Whāriki Mātauranga mō ngā Mokopuna o Aotearoa: Early Childhood Curriculum. Wellington, New Zealand: Learning Media. Available at: http://www.education. govt.nz/early-childhood/teaching-and-learning/ece-curriculum/te-whariki/

Ministry of Education (2013) Ka hikitia: Accelerating success 2013-2017. The Māori education strategy. Wellington, New Zealand: Ministry of Education. Available at: http://www.education.govt.nz/assets/ Documents/Ministry/Strategies-and-policies/Ka-Hikitia/KaHikitiaAcceleratingSuccessEnglish.pdf

Ministry of Social Development (2010) The social report. Wellington, New Zealand: Ministry of Social Development.

Mitchell L, Bateman A, Ouko A, et al. (2015) Teaching and Learning in Culturally Diverse Early Childhood Settings. Hamilton, New Zealand: Wilf Malcolm Institute of Educational Research, University of Waikato.

Mitchell L, Haggerty M, Hampton V, et al. (2006) Teachers, Parents, and Whānau Working Together in Early Childhood Education. Wellington, New Zealand: New Zealand Council for Educational Research.

Orange C (1987) The Treaty of Waitangi. Wellington, New Zealand: Allen and Unwin/Port Nicholson Press.

Pearson E (2011) Avoiding recolonisation in early childhood: Promoting local values as mediators in the spread of globalisation. Contemporary Issues in Early Childhood 12(3): 212-223.

Rao N and Chan CKK (2009) Moving beyond paradoxes: Understanding Chinese learners and their teachers. In: Chan CKK and Rao N (eds) Revisiting the Chinese Learner: Changing Contexts, Changing Education. Hong Kong, China: Comparative Education Research Centre, University of Hong Kong, pp. 3-32.

Rao N, Ng SSN and Pearson E (2009) Preschool pedagogy: A fusion of traditional Chinese beliefs and contemporary notions of appropriate practice. In: Chan CKK and Rao N (eds) Revisiting the Chinese Learner: Changing Contexts, Changing Education. Hong Kong, China: Comparative Education Research Centre, University of Hong Kong, pp. 255-279. 
Ritchie J and Rau C (2006) Whakawhanaungatanga - partnerships in bicultural development in early childhood education. Final Report to the Teaching and Learning Research Initiative Project. Wellington, New Zealand: Teaching and Learning Research Institute. Available at: http://www.tlri.org.nz/tlri-research/ research-completed/ece-sector/whakawhanaungatanga $\% \mathrm{E} 2 \% 80 \% 94$-partnerships-bicultural-development

Ritchie J and Rau C (2008) Te puawaitanga - partnerships with tamariki and whānau in bicultural early childhood care and education. Final Report to the Teaching and Learning Research Initiative. Wellington, New Zealand: Teaching and Learning Research Institute. Available at: http://www.tlri.org.nz/tlriresearch/research-completed/ece-sector/te-puawaitanga-partnerships-tamariki-and-wh\%C $4 \% 81$ nau

Ritchie J and Rau C (2015) Poipoia te tamaiti kia tū tangata: Identity, belonging and transition. The First Years. Ngā Tau Tuatahi 17(2): 39-46.

Rivalland CMP and Nuttall J (2010) Sameness-as-fairness: Early childhood professionals negotiating multiculturalism in childcare. Early Childhood Folio 14(1): 28-32.

Royal Society of New Zealand (2013) Languages in Aotearoa New Zealand. Available at: http://www.royalsociety.org.nz/expert-advice/information-papers/yr2013/languages-in-aotearoa-new-zealand/

Shonkoff JP (2010) Building a new biodevelopmental framework to guide the future of early childhood policy. Child Development 81(1): 357-367.

Simon J (1990) Good intentions, but ... . In: Steele R (ed.) Whakamana Tangata: A Beginner's Guide to Cultural Identity. Wellington, New Zealand: Ministry of Education, pp. 38-42.

Skerrett M (2007) Kia tū heipū: Languages frame, focus and colour our worlds. Childrenz Issues 11(1): 6-14.

Spoonley P (2014) New diversity, old anxieties in New Zealand: The complex identity politics and engagement of a settler society. Ethnic and Racial Studies 38(4): 650-661.

Spoonley P and Bedford R (2012) Welcome to Our World? Immigration and the Reshaping of New Zealand. Auckland, New Zealand: Dunmore.

Statistics New Zealand (2013) 2013 census. Available at: http://www.stats.govt.nz/Census/2013-census/

Tobin J, Arzubiaga A and Adair JK (2013) Children Crossing Borders: Immigrant Parent and Teacher Perspectives on Preschool. New York: Russell Sage Foundation.

Tobin J, Arzubiaga A and Mantovani S (2007) Entering into dialogue with immigrant parents. Early Childhood Matters 108: 34-38.

Waitangi Tribunal (2011) Ko Aotearoa tenei: A report into claims concerning New Zealand law and policy affecting Māori culture and identity. Wellington, New Zealand: Waitangi Tribunal.

Walker R (2004) Ka Whawhai Tonu Matou: Struggle without End. Rev. ed. Auckland, New Zealand: Penguin. Ward U (2009) Working with Parents in Early Years Settings. London: Learning Matters.

Weber E (2015) Envisioning South-South relations in the fields of environmental change and migration in the Pacific Islands - past, present and futures. Bandung 2(6): 1-21.

Wong YH and Leung TKP (2001) Guanxi: Relationship Marketing in a Chinese Context. New York: International Business Press.

Woodrow D and Sham SYM (2001) Chinese pupils and their learning preferences. Race, Ethnicity and Education 4(4): 377-394.

Wu B (2011) Whose Culture Has Capital? Class, Culture, Migration and Mothering. Bern: Peter Lang.

Wu J and Singh M (2004) 'Wishing for dragon children': Ironies and contradictions in China's education reform and the Chinese diaspora's disappointments with Australian education. Australian Educational Researcher 31(2): 29-44.

Yuen G and Grieshaber S (2009) Parents' choice of early childhood education services in Hong Kong: A pilot study about vouchers. Contemporary Issues in Early Childhood 10(3): 263-279.

\section{Author biographies}

Angel Chan is a Lecturer in the School of Curriculum and Pedagogy at the University of Auckland, New Zealand. Her teaching and research aim at promoting social justice and cohesion by supporting teachers to develop inclusive pedagogies in order to work collaboratively with diverse families.

Jenny Ritchie is an Associate Professor at the Victoria University of Wellington, New Zealand. Her teaching, research and writing have focused on supporting early childhood educators and teacher educators to enhance their praxis in terms of cultural, environmental and social justice issues. 